\title{
日本人の脳血管障害 (抄録)
}

\section{九州大学医学部第二内科 藤島正敏}

\section{はじめに}

脳卒中は致死率が高く，先進諸国では主要死因の 1 つに数えられる。まだ、脳卒中は死に至らずとも，片 麻㿎, 言語障害, 知的機能障害など身体機能に著しい 障害をきたす，とくに，日本人は脳卒中のリスクが他 の民族と比べて高く，わが国の身体障害（寝たきり） や痴呆の原因となっている。したがって, 脳卒中の予 防は，わが国の成人病対策に括ける最も重要な課題の 1つである。

近年, わが国では高秢人口の急速な増加や, 食生活 を含む生活習慣の欧米化比よって，心血管病の疾病構 造に変動がみられ，脳卒中の病態も変化しつつある。

本報告では, 当教室が福岡県糟屋郡久山町に招いて, 長年継繶している心血管病の疫学調査 (久山町研究) の成績を中心に, 日本人の篦卒中の特徵, 要因, 時代 的変化について述べる。

\section{1. わが国の脳卒中死亡率の動向}

わが国の人口動態統計”から，日本人口の年龄構成 の時代的変化の影響を除くため年齢補正をして，脳卒 中（脳血管疾患）死亡率の時代的推移を検討した（図 1).脳卒中死亡率は, 1950年前半加引1960年代後半ま で緩やかに上昇し，しかる後に減少傾向に転じている。 その結果，1950年代前半に結核を抜いて死因の第 1 位 の座を占めた脳卒中は，1980年には悪性新生物にその 座をずり，1985年には心疾患にも追い抜かれて，現 在では死因第 3 位の位置まで後退した。这卒中死亡率 を病型別にみると，1951年に䢙卒中の大部分を占めて いた脳出血の死亡率は，その後着実に減少しているの に対し，脳梗塞の死亡率は1970年まで增加し，その後 一貫して低下傾向を示している。一方，くも膜下出血 の死亡率は，1950年代に急速に増加した後に緩やかな 増加傾向を示していたが，1990年代になってほぼ横這 いとなった。

脳卒中死亡者数は，1951年の約10万人から1970年の 約18万人まで增加した後に減少傾向に転じて，1991年

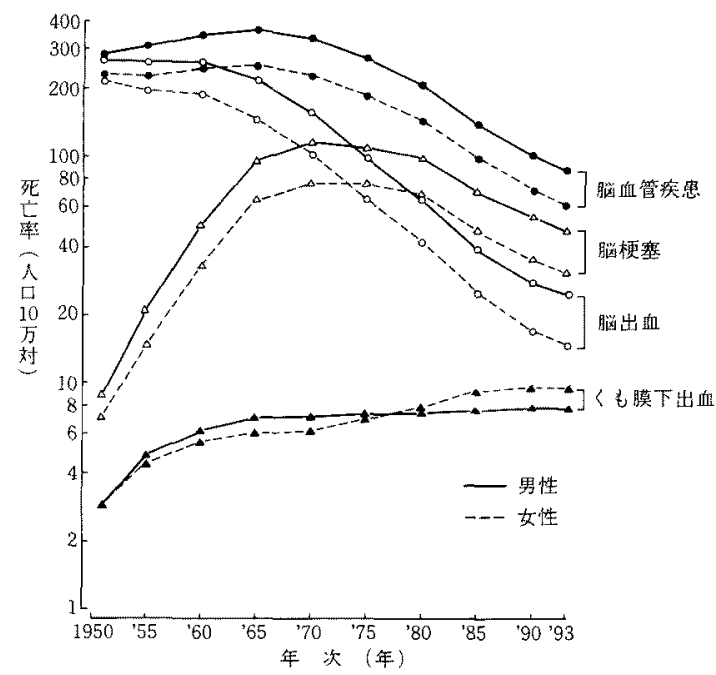

図 1.わが国の年龄調整脳卒中死亡率の年次推移, 基 準人口：1985年モデル人口，資料：厚生省「人口動 態統計」

以降では11万 8 千人台で推移し, 増減がみられない。 病型別にみると, 㮸出血の死亡者数は1950年代から 1960年代にかけて10万人前後で推移した後に隇少傾向 となり，1992年以降では 3 万人以下となっている。そ れに対して，脳梗塞の死亡者数は，1951年の3万人加 ら1980年の 7 万 5 干人まで增加し, しかる後に減少傾 向に転じているが, 1990年代に入って6万人台で横逭 いに推移している。一方，〈も膜下出血による死亡者 数は，1951年の千 5 百人から，1993年の 1 万 3 千人ま で一貫して増加傾问にある。

以上の成績から, 近年わが国では, 脳卒中の年粭調 整死亡率は減少傾向にあるにもかかわらず，死亡者数 纯必ずしも隇少していないことがうかがえる。これは， 日本人口の高齢化によって, 脳卒中のリスクが高い高 齢者が増加していることに起因すると考えられる.今 後さらに高齢者が增えると考えられることから，仮に 脳卒中のリスクが減少し，その死亡率が低下しても， 

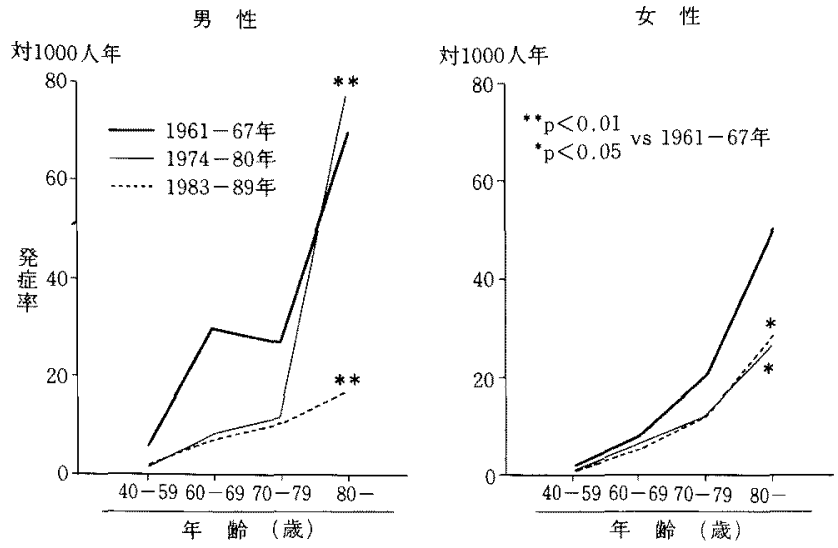

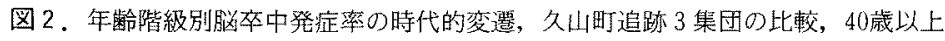

脳卒中の有病者あるいは死亡者数そのものは逆に増え る可能性が高い。

\section{2. 脳卒中発症率の時代的推移}

死亡統計は，死亡診断者の死因を集計して作成され ているが, 死亡䛦断書の正確性が時代とともに変化し ていることや,死沉至らない軽症例を反映しないなど, その解釈に当たっては留意しなければならない点があ $る^{2}$. 軽症例を含めた脳卒中の時代的変化を正確に把 握するには，地域社会における脳卒中発症率の動向を 長期以わたり観察する必要がある。そこで，日本人の 代表的なサンプル集団（人口構成，職業構成が全国の それと一致)である久山町住民を対象にした疫学調查 の成績から，日本人の脳卒中発症率の時代的変化を検 討した。

1961年に久山町の成人検診を受診した満40歳以上の 住民のうち，脳卒中の既往がない1621名を研究前期 (1960年代)の集団, 1974年の検診受診者2053名を中期 （1970年代）の集団，1983年の検診受診者2474名を後期 (1980年代)の集団とし，それぞれ6年間追跡した成績 から，脳卒中発症率を年齢階級別に算出・比較した(図 $2)^{3)}$ ，(2ずれの集団も当該年齢人口の $80 \%$ 以上を含ん でおり，偏りがほとんどないと考えられる。また，1960 年代の集団は高血圧治療が普及する以前の集団で, 1970年代以降惊血压治療の影響を受けた集団であ る.

男性の脳卒中発症率は，1960年代から1970年代にか けて40歳から80歳末満の年坽層で低下したが,80歳以
上ではその低下はみられない．1980年代になると，80 歳以上の高喻者の発症率も低下したが，80歳末満の年 龄層では1970年代と比べて変化はみられない。一方， 女性の発症率は，1960年代加ら1970年代にかけて全年 齢層で低下したが，1970年代と1980年代の間ではほと んど変化していない.

$3 つ の$ 集団の脑卒中発症率（対千人年）を年跲階級 を調整して比較すると，1960年代では男性15.7，女性 8.3で，男性のリスクは文性の 2 倍であったが，1970年 代にはそれ発れ6.5，5.5となり，男女とも1960年代に 比へて有意に減少した。とくに, 男性の発症率の減少 が大きく，男女差が大幅に縮まった，その後，1980年 代の脳卒中発症率は男性 5.5 , 女性5.6で，1970年代と 比べてはとんど変化なく，男女差もなくなったことは 留意すべきことである。脳卒中を脸梗塞, 脳出血, ク モ膜下出血の病型に分けても, 同様の傾向が認められ ている.つまり，1980年代に入ってからは，80歳以上 の男性高齢者を除いた全ての年噛階級で，脳卒中発症 率の低下傾向が鈍化し，ほほ横這い状態となっている。

\section{3. 日本人の脳卒中の特徵}

表は，久山町の第 1 集団と第 2 集団をそれぞれ 10 年 間追跡した成績から, 脳卒中のタイプ別の頻度を算出 し4，欧米の登録研究の成績 ${ }^{5 \sim 9)}$ と比較したものであ る.脳梗塞は発生機序により, 穿通枝系梗塞(ラクナ 梗塞), 皮質枝系梗塞(アテローム硬化による脳血栓), 脳塞栓の 3 群に分けた。欧米の報告では，相対的に皮 質枝系梗塞放よび脳塞栓の頻度が高いが, 久山町では, 
表. タイプ別脳梗塞㧍よび脳出血の頻度の国際比較

\begin{tabular}{|c|c|c|c|c|c|c|}
\hline \multirow{2}{*}{ 調 } & \multirow{2}{*}{ 期間 (年) } & \multirow{2}{*}{ 人数 } & \multicolumn{3}{|c|}{ 遒 梗 塞(\%) } & \multirow{2}{*}{ 脳出南 $(\%)$} \\
\hline & & & 穿通枝系 & 皮質枝系 & 脳梗塞 & \\
\hline $\begin{array}{l}\text { Harvard Cooperative } \\
\text { Srtoke Registry, USA }\end{array}$ & $1972-?$ & 649 & 20 & 36 & 33 & 11 \\
\hline $\begin{array}{l}\text { Pilot Stroke } \\
\text { Data Bank, USA }\end{array}$ & $1980-81$ & 809 & 12 & 21 & 25 & 12 \\
\hline South Alabama, USA ${ }^{7}$ & 1980 & 151 & 13 & 48 & 28 & 9 \\
\hline $\begin{array}{l}\text { Lausanne Stroke } \\
\quad \text { Registry, Switzerland }{ }^{83}\end{array}$ & $1982-?$ & 1,000 & 13 & 39 & 16 & 11 \\
\hline Austin, Australiag) & $1977-80$ & 616 & 21 & 32 & 8 & 6 \\
\hline \multicolumn{7}{|l|}{ 久山町研究 } \\
\hline 第 1 集困 & $1961-71$ & 132 & 50 & 13 & 10 & 22 \\
\hline 第 2 集団 & $1974-84$ & 128 & 44 & 15 & 20 & 18 \\
\hline
\end{tabular}

逆に穿通枝系梗塞と脳出血の割合が大きい.脳出血は, 主に大脳基底核領域に分布する 300 ミクロン以下の等 通枝動脈の血管罗死と微小動脈留の破綻によって䓯起 される、したがって，日本人では，穿通枝系の動脈硬 化が強いことが特徴といえる。このタイプの細小動脈 硬化は，高血圧が最も強いリスクになることが知られ ている。

久山町 2 集団を比較すると，第 2 集団では，穿通枝 系梗塞と脳出血の割合が減少し, 逆に脳塞栓の割合が 増加傾向にある。これを脑卒中発症率でるると，第 2 集団の穿通枝系梗塞と脳出血の発症率は第 1 集団と比 べて有意に減少したが，皮質枝系梗塞と脳塞栓の発症 率には有意な変化はなかった。また，久山町剖検例の 被款部動脈を検索した成績では，第 2 集団の血管壊死 の頻度は第 1 集団と比べて有意に減少していた ${ }^{109}$.こ うした事実は，第 2 集団では高血圧管理が普及して, 穿通枝系の動脈硬化が軽減したことを示㖫している。

\section{4. 危険因子の時代的推移}

久山町の膇卒中発症率が過去 30 年間大きく変化した 背景には，その危険因子の時代的変化が考元られる。 そこで，1961年，1973〜 74年，1988年の3 時点に行っ た40歳以上の住民検診加ら，心血管病の危険因子の時 代的推移を検討した（図 3$)^{11}$. 高血圧 (血圧 $\geqq 160 / 95$ $\mathrm{mmHg}$ ）の頻度は 1961 年の男性 $27 \%$ ，女性 $24 \%$ 加ら， 1988年には男女とも14\%まで漸隇した。この間，降圧 薬常用者は男女とも1961年の $2 \%$ 加ら1988年の14\%に まで增加していた。また，20年間隔で行った栄責調査 では，成人1日当たりの食塩摄取量は1965年の18gか力 ら1985年には11gに減少していた 加ら1980年代にかけて，降圧薬療法の普及と食塩摄取 量の減少によって高血圧頻度が隇少したことがうかが える.

一方, 肥満 $\left(\mathrm{BMI} \geqq 25.4 \mathrm{~kg} / \mathrm{m}^{2}\right)$ の頻度は, 1961 年 では男性 $6 \%$ ，女性11\%であったが，時代とともに增 加し, 1988年では男女とも20\%に達している11).をれと 平行して, 高コレステロール血症 ( $\geqq 220 \mathrm{mg} / \mathrm{dl})$ の頻 度は1961年の男性 3\%，女性 7\%から，1988年以はそ れぞれ28\%と42\%までに增えた。な扔，1988年では， 40〜79歳の受晾者全員に経口梼負荷試験を行い，耐糖 能異常の頻度を検討した. その結果,WHO基準による 糖尿病の有病率は約10\%, IGT (impaired glucose tolerance）の有病率は20\%に達していた。

男性の喫煙者は近年になってようやく減少傾向にあ るが，末だ 40 歳以上の半数が喫煙者であり，欧米諸国 の20〜30\%と比べてその頻度は高い. 一方，女性の契 煙者は従来より少ないが,最近では10\%以下となった。 飲酒者の頻度にほとんど変化はみられない。

脳卒中の最大の危険因子である高血圧の頻度は, 1980年代になっても減少傾向にあるにもかかわらず， 前述のごとく，1980年代になって脳卒中発症率の減少 傾向は止まり横這いとなっている。その理由の1つは， 高脂血症や耐糖能異常など代謝異常の頻度が近年大楅 に増え，降圧治療による脳卒中の予防効果を相殺して いる可能性が考えられる。 

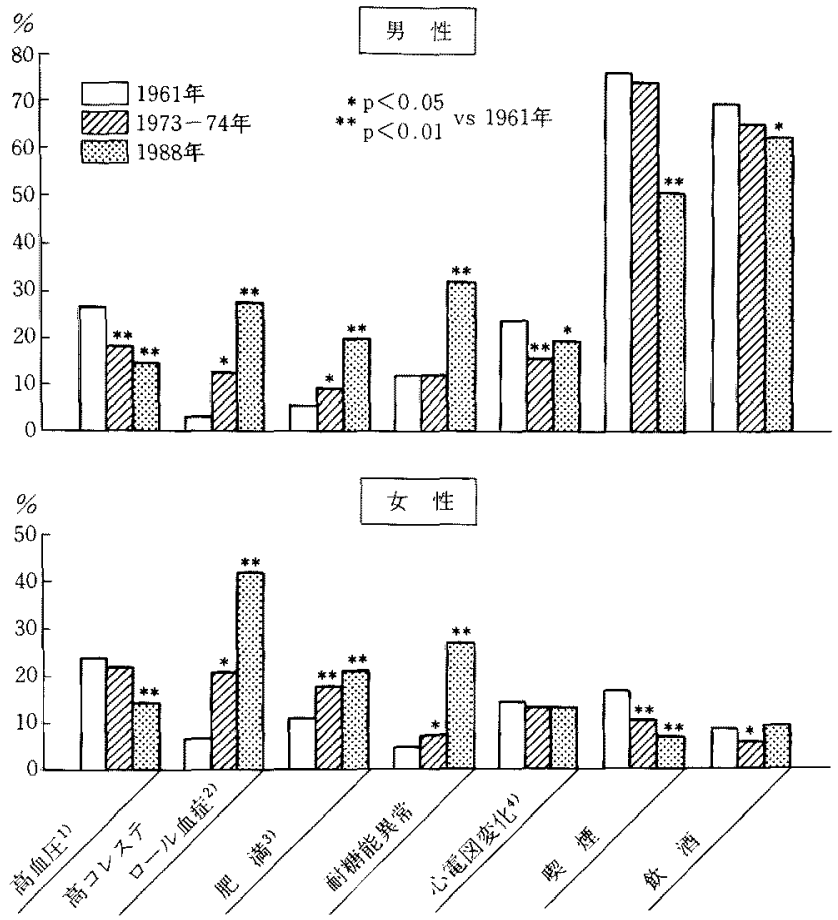

1) $\mathrm{SBP} \geq 160 \mathrm{mmHg}$ またはDBP $\geq 95 \mathrm{mmHg}, 2) \geq 220 \mathrm{mg} / \mathrm{dl}$,

3) $\left.\mathrm{BMI} \geq 25.4 \mathrm{~kg} / \mathrm{m}^{2}, 4\right)$ メネソタコードIII-1または $[\mathrm{V}-1,2,3$

图 3. 盺面調查にちける心血管系挨患の危険因子の時代的推移 久山町男女, 40 歳以上, 年踣調整

\section{まとめ}

わが国では，過去数十年間に脳卒中の死亡率，発症 率は大幅に減少した。これは高血圧管理をはじめとす る，わが国の脳卒中の予防対策の成果といえよう。し かし，このような努力にもかかわらず，日本人口の高 路化によって，脑卒中患者数はむしろ増える可能性が ある。また，日本人の生活様式の欧米化によって，肥 満, 高脂血症, 糖尿病などの代謝異常者が増え, これ らが脑卒中の危険因子として台頭している，脳卒中を 今後さらに隇少させるには，脳卒中の最大の危険因子 である高血圧の予防・治療・管理を引き続き徹底させ るとともに，代謝異常など高血圧以外の脳卒中危険因 子を早期以発見し，その予防対策を構じることが重要 である。しかし，高齢者の脳卒中をいかに予防するか は必ずしも明らかにされておらず，今後解決すべき大 きな課題といえよう。
久山町研究協力者：故勝木司馬之助, 尾前照雄, 高野朔太 郎, 廣田安夫, 石神俊德, 武谷 溶, 赤染種彦, 竹下司恭, 武谷 伸, 中野昌弘, 中村定敏, 三井久三, 田中精二, 上月 武志, 仲村吉弘, 池田寿雄, 日吉雄一, 酒井 正, 上田一雄, 喜久村徳清, 岡田光男, 坂田博美, 志方 建, 藤井一朗, 蓮 尾 裕, 梁井俊郎, 屋宮央哉, 清原 裕, 益田順一, 輪田順 一, 河野英雄, 梶原英二, 加藤 功, 野見山賢介, 大村隆夫, 新川 淳, 岩本廣満, 中山敬三, 大森 将, 吉武毅人

$$
\text { 文献 }
$$

1）厚生省大臣官房統計情報部：平成 5 年人口動態統 計。厚生統計協会, 1995.

2) Hasuo $Y$, et al: Accuracy of diagnosis on death certificates for underlying causes of death in a long-term autopsy-based population study in Hisayama, Japan; with special reference to cardiovascular diseases. J Clin Epidemiol 42: $577,1989$.

3) Kiyohara $X$, et al: Changing patterns in prevalence of dementia in a Japanese community: 
The Hisayama study, Gerontology 40:29, 1994.

4) Kiyohara $Y$, et al: Type-specific incidence of cerebral infarction and its changing pattern during the long-term prospective population sur. vey in Hisayama town, Japan.Stroke 21: 1-35, 1990.

5) Mohr JP, et al: The Harvard Cooperative Stroke Registry: A prospective registry. Neurology $28: 754,1984$.

6) Kunitz SC, et al: The Pilot Stroke Data Bank: Definition, design and data. Stroke 15: 740,1984

7) Gross CR, et al: Stroke in South Alabama : Incidence and diagnostic features $-A$ population based study. Stroke 15: 249, 1984.

8) Bogousslavsky J, et al : The Lausanne Stroke Registry: Analysis of 1,000 consecutive patients with first stroke. Stroke 19: 1083, 1988.

9) Chambers RB, et al: Patterns of stroke. An analysis of the first 700 consecutive admission to the Austin Hospital stroke unit. Aust NZ J Med $13: 57,1983$.

10) Masuda J, et al : Cerebrovascular disease and their underlying vascular lesions in Hisayama, Japan-A pathological study of autopsy cases. Stroke 14:934, 1983.

11) Fujishima M, et al: Smoking as cardiovascular risk factor in low cholesterol population: The Hisayama study. Clin Exp Hypert A14: 99 , 1992.

12) Kato I, et al: Serum lipids and nutritional intake in a Japanese general population: The Hisayama study. Ann NY Acad Sci 676: 331, 1993. 